\title{
Subject Exclusion Reason
}

National Cancer Institute

\section{Source}

National Cancer Institute. Subject Exclusion Reason. NCI Thesaurus. Code C103160.

The explanation given as to why a subject was prevented from being allowed to participate in a study. 